EASTERN REVIEW 2020, T. 9

\author{
Daria Yashkina \\ (iD https://orcid.org/0000-0003-4454-4555 \\ V.N. Karazin Kharkiv National University, Ukraine \\ Department of Political Sociology \\ e-mail: yashkinadarya96@gmail.com
}

\title{
A sociological perspective on the phenomenon of solo-living in Eastern Europe: An attempt at conceptualization
}

\begin{abstract}
This article examines the phenomenon of solitary living as a consequence of the processes of individualization that are characteristic of the entire modern world. The urgency of this problem arises from the increase in the number of individuals who prefer to live alone. Although this trend is typical for Eastern Europe, as it is for the rest of the world, it is not widely considered in scientific circles. Whilst analyzing scientific literature in different spheres (philosophy, economics, psychology, sociology) and statistical data on solitary living, the author has come to the conclusion that to describe the phenomenon in a sociological vein, it is most appropriate to consider solitary living as a "solo-living" lifestyle. The article also examines the main studies of solitary living in Eastern Europe, and through such work, it was concluded that there is not enough research: current research mainly considers single living among the older generation, despite the fact that the number of young people who prefer this lifestyle continues to grow. In the course of the study, the author was faced with the problem of layering related concepts: solos, singles, solo-living, single-person households, and others. To avoid this problem, the author distinguishes between these concepts and makes an attempt to conceptualize the concept of "solo-living", offers the author's definition, and outlines further research prospects.
\end{abstract}

Keywords: individualization, lifestyle, solo-living.

In the social sciences, the concept of individualization is considered from different methodological and worldview positions, but the fact remains that individualization is a significant process and a consequence of social changes that characterize modern societies. Almost all social sciences pay attention to the study of individualization. So, in philosophy, this process is considered as a process of an individual's self-knowledge in the context of the cognition of the essence of being as such: as a process of an 
individual gaining freedom (S. Kierkegaard, H. Berdyav, M. Buber) ${ }^{1}$; psychology studies the process of individualization in the context of personality development, the implementation of individual inclinations, the course of the corresponding mental processes (K. Jung was among the first to work on individualization as the key of psychology, A, Mindell, G. Simondon); economics examines the impact of individualization processes on market relations and the market as a whole, as well as the individualization of production processes - F. Hayek (Khayyek, 2000), J. Pine, V. Radaev. Sociology, on the other hand, considers the processes of individualization as a complex phenomenon that influences the life of society in all spheres of social life, its influence on the style characteristics of life, the formation of new ways of living, etc. (U. Beck and E. Beck-Gernstein, Z. Bauman, R. Sennett, A. Hochschild).

As a consequence of such scientific popularity, the concept of individualization has a fairly wide spectrum of definitions, each of which focuses on one or another characteristic of the process. In our view, individualization is a process characteristic for the society of the second modernity (according to U. Beck), which is a consequence of social changes and represents a change in the stylistic characteristics of the lifestyle of individuals in the direction of the individual's isolation: one of the main characteristics of individualization is the expansion of the choice of the individual (according to E. Durkheim).

At the same time, individualization itself leads to many different kinds of consequences, to which many studies are devoted. So, for example, individualization leads to the emergence of new forms of partnerships, a modification of the forms of partnerships: relationships at a distance (for example, in the work of Sandra Krapf, she divides relationships at a distance into either long or short, and considers, which type of relationship turns out to be the most durable (Krapf, 2017), weekend families, polyamory, etc.

Separately, a category of people is distinguished who, one way or another (forced or not; consciously or unconsciously), refuse to enter a relationship, or do not refuse, but distance themselves from them. Also, there are more and more people who prefer living alone, this trend covers almost the whole world. Thus, $40 \%$ of American households consisted of 1 person as of 2012 (Klinenberg, 2018), and in 2019 the number of single households reached 36.48 million (Statista, 2020b). According to the forecasts of the director of the Center for Family and Population Research of the University of Singapore: Wei-Jun Jean Yeung, by 20204 out of 10 households will be single-person. Furthermore, leading in the number of single households will be Asian countries: as of 2015, 28\% of Japanese households consisted of one person (Yeung, 2020). This trend is observed not only in the US and Asia, but also in Europe. As of 2019, the number of people living alone in the UK has increased by $20 \%$ since 1999 to reach 8.2 million

\footnotetext{
${ }^{1}$ For example Berdyaev, 1994.
} 
(Office fornational statistic, 2020). The largest number of singles in Europe is found in Scandinavia: in 2017, 51\% of households in Sweden were single (Ec.europa.eu, 2020b), and in Norway as of 2019, single households make up $43 \%$ of all households (Statista, 2020a). Of course, even though the trend is common for everyone, each region has its specifics, due primarily to cultural characteristics.

Eastern Europe is of particular interest in this context. Eastern Europe is a region of Europe, a significant part of which is made up of post-Soviet countries. Accordingly, this region is characterized by both cultural and value specificity, which affects both the development and course of individualization processes in general, and the trend towards an increase in the number of individuals who live alone, in particular. Considering the value slice of the European Study of Values, the Russian researchers V. Magun and M. Rudnev concluded that among all the studied countries, the citizens of Eastern Europe are the least open to changes and place the highest value on preserving, while their value of self-resistance remains at the average level (Magun, Rudnev, 2011)2. In Western European countries, the indicators are opposite, and, it would seem, in these conditions, the dynamics of growth in the number of people living alone should be different in Eastern European countries. However, in Eastern Europe, the percentage of single households is quite high: in Estonia - 40\%, Slovakia - 43\% and in Latvia - 44\% - in 2017 (Ec.europa.eu, 2020b). And for the period from 2010 to 2019, Lithuania became one of the leading European countries in terms of the dynamics of decreasing household size (Ec.europa.eu, 2020a). Despite the statistics, studies on this issue of Eastern European countries are practically absent.

Thus, we see that single households are becoming more and more common and, accordingly, the question of the consequences of such changes is becoming more and more urgent.

When analysing scientific literature on the topic presented, many different concepts describe a similar phenomenon: solos, singles, solo-living, single-person households, and others - each of them carries an adjacent, but at the same time, different semantic load. The problem in this situation is that there is no clear distinction between them, and more and more such concepts are emerging; moreover, there is a kind of layering of some concepts on others. In our opinion, the most "suitable" concept for considering solitary living in a sociological vein is that of "solo-living", however, the concept does not have a clearly established definition and, as a result, requires conceptualization and operationalisation.

The purpose of this article is an attempt to conceptualize "solo-living" and delimit it from related concepts.

2 The research Basic values: similarities and differences between Russians and other Europeans by V. Magun, M. Rudnev, was conducted on the basis of the 4th wave of the European Social Research (2008-2009). 
To realize this goal, the logic of the presented article will be structured as follows: the general conditions for the emergence of the phenomenon of "solo-living" from the sociological point of view will be considered, which will determine the framework for studying the phenomenon from the standpoint of this science. Further, it will be determined how exactly solitary living in the social sciences are considered and what place among the different readings and understandings of solitary living is occupied by "solo-living"; also the ratio of various related concepts will be considered. Based on the information received and its analysis, a conceptualization of "solo-living" will be proposed.

Speaking about the conceptual foundations of the sociological study of solitary living, one should pay attention to the fact that despite the generally accepted ideas about man as a collective being, Georg Simmel, one of the founders of sociology, argued that a person is not a purely collective being or a purely individual one (Simmel, 1909), so we should talk about the balance of these traits or the prevalence of one over the other. Over time and the development of society, the individual has more and more weight relative to the collective. Emile Durkheim expressed a similar idea: he linked individualization with the division of labor. The sociologist said that with the transition to an industrial society, the type of solidarity of individuals changes: from mechanical to organic solidarity. And if the first type was based on the similarity of members of society, then the organic type of solidarity presupposes a functional division of members of society in joint work, thereby the formation of the individual and the awareness of oneself as separate. However, there also comes the realization that freedom and independence inherent in the cult of personality, according to E. Durkheim, are possible only when individuals are united (Durkheim, 1996). Individualization is a process that accompanies social development. At the same time, the conditions of modernity cause adjustments to the processes of individualization. Modernity is considered by W. Beck (who considered it as an increase in risks) and Z. Bauman (who spoke about fluidity and variability) as having entered the era of the second modernity and is characterized by instability, including social institutions, practically impossible long-term planning, where the solution of the problems and difficulties that an individual faces in life become an exclusively individual's business. In such conditions, the processes of individualization cover all spheres of life in a society, the main prerequisites for such an all-encompassing influence of individualization are the division of labor, the development of legal consciousness, and urbanization, etc. Thus, the foundations of the perception of oneself as being separate from others and the awareness of one's rights and freedoms, as well as the delimitation of one's freedom are formed from the freedom of another. But apart from the fact that the individual defines freedom, he also sees the need to cope with "life challenges" (Bauman, 2008) on their own. And here a kind of family crisis arises in the sense that the interests of the family begin to contradict the interests of the individual, and the interests of the individual 
become higher than those of the family. This is the basis for the transformation of family forms. And the family becomes, in essence, a partnership/union based on an unspoken agreement for predominantly emotional exchange, while individual goals: education, career, etc., are in the first place. Under such conditions, non-family forms of partnership develop. So, considering the era of developed modernity, Sigmund Baumann, Wilrich, and Elizabeth Beck say that a single man or a single woman takes the place of the family as a unit of society.

Such changes can be perceived optimistically or pessimistically, both to the family, as to social institution, and interpersonal relations as such: loss or weakening of social ties, due to radical individualism (following the logic of Z. Bauman), increased feelings of risk (according to W. Beck). From an optimistic point of view, living alone is not cutting off social ties as such, but creating a foundation or platform for maintaining close relationships with others: it is about expanding the space for building and strengthening social ties, outside of established norms and traditions. The phenomenon of singles and single households or single living gradually begins to develop and spread. Also, the emergence of this phenomenon is associated with the active processes of urbanization in the same period of industrialization. For example, the American family researcher William Goode argued that as the level of urbanization increases, nuclear families are gaining more popularity and crowding out extended ones, and as household sizes are shrinking, nuclear families are more effective (Burova, 2010). In modern conditions, we see how households are shrinking down to single-person ones. The aforementioned G. Simmel saw in urbanization a mechanism that drives the development of individualization processes. According to the sociologist, a large city provides an individual with more opportunities and removes restrictions, unlike a small village, a city gives freedom of movement, the opportunity to visit groups of interests, etc., which contributes to individualization. American sociologist-urbanist Richard Sennett also spoke about urbanization and the reduction of household size. He said that with the development of urban space, the formation of the nuclear type of family comes to the fore (Vershinina, 2012). This type of family was the most rational for running a household in an emerging urban culture: feminism had only just begun to develop, the traditional distribution of roles still worked, and the maintenance of extended families in the city was already economically disadvantageous (Yashkina, 2020). Accordingly, in the era of the so-called second modernity, the tendency for an increase in the number of people living alone can be explained by the processes of individualization in the conditions of urbanization and the "fluidity" and instability of modern life as such; the active development of feminist movements and the formation of a female individuality also play a separate role in these processes. However, this is only a general framework and conditions for the emergence and spread of this phenomenon.

Looking at the studies of single living, we see that the main studies of singles in Eastern Europe are, as mentioned previously, about ageing populations and changes in family structure. Eastern Europe is seen as the region with the most 
rapid social and economic changes over the past few decades. Naturally, people there associate the concept of the family with communist vulgarity. Thus, the family, which was one of the main values of Soviet society, is undergoing the most radical changes: a decrease in the birth rate, an increase in the number of divorces, an increase in the number of single parents, etc. This is largely due to the economic situation in which the countries found themselves after the collapse of the Union - exorbitant levels of poverty, unemployment (Robila, 2004). However, against the backdrop of research on the decline of the family, there is little research on the phenomenon of solitary living, except for those related to the ageing population. This is due to the fact that the ageing of the population is an urgent problem for the countries of Eastern Europe: among all lonely people in Eastern Europe, the predominant part is the elderly population. In Slovakia, for example, young people living alone (aged 15 to 29$)$ represent only $1 \%(O E C D, 2019)$ of the population.

A Polish study of the living standards of elderly people living alone suggests that

a single household is run by married people who manage their family budget separately. Older people who want to maintain their independence in terms of budget and property deliberately take on a one-person household, despite the fact that they are in a relationship with a partner. With regard to these households, the highest standard of living was demonstrated (51.2 points), among divorced persons the standard of living was slightly lower (50.3 points), and among widowed persons, even lower (49.6 points) (Piekut, 2020).

That said, the study found that elderly people do not always live alone because they have to, but also as a conscious choice: the choice not to move to relatives after the death of their spouse, the choice to live separately from their spouse, the choice to remain without a spouse, etc. The study of older people in Latvia Older People Living Alone: Trends, Profiles and Challenges of Intergenerational Integration (2019) suggests that the situation of choice for older people is very illusory, since more often older people simply do not want to impose themselves on relatives and so on, and thus this part of the population is most at risk of social exclusion:

The study showed that the frequency of communication with other people for many elderly people in Lithuania actually fluctuates on the verge of what many researchers consider social isolation since it does not even reach one person a day ( 9 people in 10 days) for single people. And for those who live with others, it is slightly higher (13 people in 10 days). $5.7 \%$ of single people aged 60 and over in Lithuania did not communicate with anyone in the week before the survey. Almost one-fifth of elderly people in Lithuania (18\%) have unstable social relationships, that is, they do not have relatives or friends to ask for help in difficult times (Mikulioniene, Rapoliené, 2019).

Therefore, the research mostly comes down to the socio-psychological aspects of living alone. At the same time, the growth of single-living elderly people is associated not only with the death of a partner but also as a result of the 
increased rate of divorces. As already indicated, there is a fairly large percentage of people living alone in the Baltic States - it is worth noting that in the Baltic countries the number of divorces has increased more significantly after the collapse of the Soviet Union, than in other countries of Eastern Europe. This is associated with the influence of liberalization that came from Western European countries. Separately, it should be noted that the possibility of divorce has not only legal but also economic aspects. Divorce can be afforded by an individual who can independently provide for their life (Härkönen, Billingsley, Hornung, 2020). When we talk about living alone as "solo-living", the possibility of economic self-sufficiency is the defining condition. This is probably the reason why young people in Eastern Europe tend to be "solo-living" less than other young Europeans.

The Russian researcher Ksenia Abanokova, while examining the impact of macroeconomic shocks on the number of households, (Changing the structure of the household as a strategy to overcome the macroeconomic shock) concludes that during crises, the size of households tends to increase. However, at the same time, considering the dynamics of the number of single households, it was determined that they turned out to be the most stable: 0.9 is the share of single households among the studied, which did not change its status for the period from 1994 to 2013 (Abanokova, 2015). This indicator may indicate the satisfaction of those living alone with their position - on the one hand, whilst on the other hand, this may indicate the difficulty of changing this status. In Russian studies, the single form of households is regarded as "non-family": until 1994, in the censuses, individuals living separately from the family were divided into single individuals and those who live separately from the family, but have regular communication with it. Later, the census began to take into account another parameter - the economic one - and single households are those that provide for themselves. However, the researchers say that, despite the global trend, the growth of single households, as in the rest of Eastern Europe, is still observed only among the elderly population (Mironova, Prokofieva, 2018).

Thus, we see that Eastern Europe is characterized by a decrease in households, a decrease in the number of families, as such, an increase in the number of elderly people living alone. At the same time, research has been carried out mainly in demographic, economic, and psychological sections. Despite the fact that there are more elderly people among the single-living East European residents, the trend of an increase in the young population preferring to live alone has not bypassed Eastern European countries. For example, in Estonia, the percentage of young people aged 15 to 29 who live alone reaches $15 \%$ (OECD, 2019).

Researchers in the study of solitary living from other regions went a little further. In the UK census, living alone is considered as people who live alone, do not live with a partner or other family member, and do not use house-sharing (cohabitation) (Wilkinson, Tomlinson, Gardiner, 2018). According to the ONS (Office for National Statistics) forecasts, the number of single people in the UK 
will reach 10.7 million by 2039 (Ons.gov.uk, 2020). Solitary living is used here as a designation of the size of the household, while quite often in studies dealing with single households, the phrase "solo-living" is used. It replaces a single living or a single household, but, as a rule, it does not differ in substance from them, that is, it is simply used as a synonym. Thus, in the 1985 study Societal Development, Familialism and Solo Living: A Cross-National Study, the Solo index denotes "the percentage of households with one person (that is, households consisting of one person)" (Baranwal, Ram, 1985).

The very concept of a "household", most often referred to in censuses, as well as statistical and economic reports, is defined as

a person living alone, or a group of people (not necessarily related) living at the same address, who share kitchen equipment and share a hallway, living room or dining room. A household can consist of one family, more than one family, or no families in the case of a group of unrelated people (Office fornational statistic, 2019).

That is, the consideration of single-living as a type of household implies an actual fixation that does not take into account either social or socio-psychological conditions and the reasons for its occurrence. The growth in the number of such households has attracted the attention of researchers around the world. For example, the study of London households The rise of living alone in Inner London: trends among the population of working age examines the dynamics of the increase in the number of single households depending on the area of residence, demographic characteristics, etc., also describing single living as a type of household (Hall, Ogden, 2003). It was the beginning of the search for the reasons for the growth of solitary living, outside of exclusively the economy and demography, that led to the emergence of the concepts of "solo-living", "solo", "living solo" and others.

Solitary living raises questions that are difficult to answer if staying within the household survey alone. So, for example, sociologists have a question about the relationship between the concepts of "family" and "household". The essence of the issue lies in the fact that these concepts are often interchangeable in everyday life since the family is perceived as one when its members live under the same roof. In the context of family relationships, living alone can be referred to as "extrafamilial life" or "post-family life" (Chandler et al., 2004). Such definitions are left exclusively within the framework of family logic, dividing life into "before", "during", "after" and, separately, "outside", but may not be related to households in any way, since in the modern world spouses do not always live together.

The more the idea of "social" is present in the study of solitary living, the more often we see the consideration of solitary living as a special model of behaviour/way/lifestyle/life course. The project of the Research Center for Family and Relations of the University of Edinburgh Solo living across the adult life course (2005) considers life alone as a life course and designates it 
as "solo-living", thereby indicating the social component of this phenomenon. Researchers point out two aspects that are important for us: "solo-living" can be either a life choice to live without a partner, or be the result of something, for example, a break in relations; at the same time, such a course in life, despite its prevalence, is still perceived as a "departure", "deviation" from the "normal" family course. However, the study indicates that "solo-living" can also become the foundation for maintaining close relationships and is not always a "cutting off" of social relationships. It is worth noting that such a life course is not permanent and is considered as one that can be chosen, and thus in the same way can be changed (Era.ed.ac.uk, 2005).

Researchers at the same university, Lynn Jamieson, Fran Wasoff, and Roona Simpson, point to the need to separate the concepts of "solo-living", "singles" and "solos" - considering them as living conditions, marital status, and partnership status, respectively. That is, they move away from using the concept of households as such in the study of single living, but they see the problem in the fact that just going into the social sphere, the greatest confusion of concepts appears. Scientists have also concluded that the use of "single" when describing both households and, in general, single living, in essence, does not give anything, since in the UK "single" can mean both a certain legally fixed marital status, and vice versa lack of marital status. Single living cannot be designated as "single" also for the reason that long-distance relationships are quite common. That is, living alone does not necessarily mean that an individual has no partner or is not married, in the same way, that an "unpartnered" person can live with their parents, relatives, colleagues, or rent apartments with friends. Based on these subtleties of definitions, researchers have come to adopt/use the concept of "solo-living", which means alone. The researchers also point out that an essential characteristic of "solo-living" is that it is a category into which one can enter and also leave, similar to the legal and de facto status of a partnership (Jamieson, Wasoff, Simpson, 2009).

The American researcher E. Kleinenberg also, when considering solitary living, saw in it an initially social phenomenon and introduced the concept of "going solo", where the metaphoric nature of the concept is clearly visible. Rather, the author himself uses "solo life" as a metaphor that leads away from viewing solitary living as a household (Kleinenberg, 2018), but leads to considering solitary living as a particular lifestyle. Russian researcher E. Lyubimova, analysing E. Kleinenberg's research, defines "solo life" as

a separate residence of a city dweller, characterized by the presence of personalized living space (separate housing), without a partner, children and other relatives, independent household management (does not share expenses and incomes) (Lyubimova, 2018). 
In this definition, we see several significant characteristics:

1) "solo life" as the life of a city dweller;

2) "solo life" as the life completely economically independent, which excludes, for example, the phenomenon of a family at a distance, which involves the division of expenses and income.

The consideration of solitary living is also dependent on age cohorts. So, in the framework of considering how traditional families are changing in Britain, researchers S. Duncan and M. Phillips approach the question of determining single residence. In their works, the authors point out that solitary living is often associated with older people whose spouses have died or cannot live outside nursing homes or other institutions with full social support (such as hospice), but the growth of single people arises precisely due to more young people living this way. The authors point out that this category of young people is quite often stereotypically viewed as people who are unlucky in relationships, and simply cannot create a married couple and, accordingly, a familiar nuclear family (the authors immediately note that the explanatory models of such failures are different for different regions). Despite the fact that the processes of individualization penetrate more and more deeply into social life and the family is weakening in its importance, individuals who do not have the official or unofficial status of "in a relationship" are stereotypically perceived as not having achieved success in life and in official documents are designated as "single". This still has negative connotations. Researchers use in this case the concept of "solo-living" as being neutral and not having a negative connotation. They wonder if "solo-living" can become a consciously chosen way of life and be socially equal to those who live in pairs (Duncan, Phillips, 2008).

B. DePaulo, a researcher and specialist in the field of the social and psychological aspects of loneliness, also addresses the problem of stigma. For her, "solo-living" is again described as a concept opposed to "single". Since "single" can include anyone who is not married (again according to the legal definitions of different countries and official documents), and has a negative connotation, B. DePaulo uses "solo". Citing statistics, according to which people living alone make up more than a third of all unmarried people in the United States, B. DePaulo points out the difficulties of "solo-living" in the couplist world: discrimination (Unmarried.org. 2020).

Returning to the age category in the study of lonely people, K. Gartveit also includes young people in the definition of "solo-living". She speaks of "solo-living" as a privileged lifestyle for young professionals who can afford to live alone (Garthwaite, 2012). The characteristic of privilege is based on the fact that economically self-sufficient individuals who are able not only to pay for utilities, but also completely independently provide for their life, can afford to live alone.

We see that the definitions of "solo-living" are generally close to each other, but still have some differences. Common to the above definitions is the social 
conditioning of the phenomenon, all of them, one way or another, consider "solo-living" as a style, way, or strategy of life. Most of the definitions point to "youth", and also indicate the emergence of a concept in opposition to the stereotypical and negatively coloured term "single".

In addition to the confusion of concepts that we have already considered, which directly relate to "solo-living", there is a problem with related concepts. The point is that many researchers consider certain aspects and phenomena associated with solitary living (without considering "solo-living"). However, in the study of lonely people, these aspects should also be taken into account: thus, intersecting with psychology, the phenomenon of "solo-living" comes into contact with the concepts of loneliness (lonely, loneliness); in the study of families and intimacy, we inevitably come across the concepts of a relationship at a distance, living together apart, never partnered, ever married, polyamory and so on. In jurisprudence we find the single status, which we have already talked about, but it is used in other areas of research. Concepts such as singlism and sologamy are considered separately. All of them seem to be close, but at the same time, it is necessary to clearly distinguish between these concepts in order to avoid inaccuracies and inconsistencies that may arise in the study of each of them.

In psychology, health research, and social history, as well as philosophy in the study of lonely people, we see the most frequent use of the concepts lonely - as a socio-psychological characteristic of the individual, loneliness - as a state of the individual, and social isolation. All of these concepts are common in public discourse and are often used in everyday discourse: journalists, academics, and healthcare professionals often combine living alone, loneliness and isolation, and the result is widespread confusion about each condition.

In general, modern discourse in scientific circles on loneliness is focused on the fact that the postmodern era is inextricably linked with the isolation of the individual from society. The Ukrainian researcher N. Panina drew attention to the absence of a common system of values inherent in the previous (pre-modernization) lifestyle, and this is precisely what provokes a feeling of breaking ties with society (Panina, 2008). Social isolation is seen as the alienation of an individual or social group from other social groups. Social isolation is associated with the integration of individuals (and groups) into a wider social environment. This concept includes "objective" indicators of the number, type, and duration of contacts between people and the wider social environment. Therefore, a key component of isolation is the size of an individual's social network (Victor et al., 2000). That is, in essence, social isolation is a reduction in social contacts, a narrowing of the circle of communication and interactions between individuals, it can be both forced and voluntary, but for us, the main characteristic is precisely the narrowing of the individual's social networks, which separates social isolation and "solo-living". Since none of the considered "solo-living" studies consider the narrowing of social ties as its characteristic. As already mentioned, E. Kleinenberg, 
considering the combination of the phenomena of social isolation, loneliness, and solo life, says that these are three different states, and being in one of them does not necessarily mean the presence of the other two. In his research, he drew attention to a correlation that is atypical for common ideas about loneliness: for example, among 300 interviews with single Americans, many said that "nothing causes more feelings of loneliness than living in a bad marriage". E. Kleinenberg also says that lonely people are more likely to meet with friends and lead a more active social life (volunteering, participation in public organizations, etc.) (Klinenberg, 2016).

Speaking about the category of loneliness, the concept itself is also considered and, accordingly, defined in different ways: as a conflict between the desired and perceived quantity and quality of social ties; a lack of strong emotional ties (Smith, Victor, 2018). Sometimes loneliness is equated with social isolation, but, as a rule, loneliness is a psychological category based on the inner feelings and experiences of the individual. Social isolation is a socio-psychological category that considers the quantity and quality of social ties and the individual's satisfaction with them.

In addition to the collision of the phenomenon of "solo-living" with the concepts of loneliness and social isolation, "solo-living" is also inseparably accompanied by concepts derived from the study of families. Thus, the greatest contact can be observed with the concept of "lifelong singles", also referred to as "never partnered" or "permanently single". They are defined as "persons who did not enter into a foundational partnership (marriage or cohabitation) before the age of 40" (Bellani et al., 2017). This category, again, does not reflect the social context, formally fixing the history of the family status of individuals. Separate questions are raised by the age restriction of this category and reflect more the problem of intimacy and intimacy of relationships, which has nothing to do with living alone per se. On the other hand, studies of single life in middle age look at two paths to single life - "having no experience of cohabitation" and "having experience of cohabitation". On the basis of such a division, again according to formal criteria, a kind of classification of the living alone can be seen below.

This diagram shows the possible formal statuses of single people and helps to structure them by dividing them into subgroups. From the presented diagram, we also see that life-long loners are only a part of people living alone.

The problem of closeness and intimacy in conjunction with living alone arises when we turn to a fairly common form of relationship: the relationship at a distance. The problem comes from the fact that researchers cannot clearly correlate formal statuses (single, lifelong single) and long-distance relationships. The Lithuanian researcher I. Jurkan-Hobain talks about what kind of relationships can be at a distance; an additional problem of such relationships is that the issue of maintaining these relationships is actually hushed up. In her work, she identified several types of relationships at a distance: 1. Living Apart Together - relationships where each individual lives separately, but within the same city/ district, while identifying themselves as a couple. 2 . If we are talking about long- 
-distance relationships: different dialects, countries, etc., then they are defined by the concept of Long-distance relationships. 3. The third most common type of non-coexistence is commutes - partners can have a commonplace of residence, but each of them has their own separate housing where they live, most often this can be associated with the career of partners.
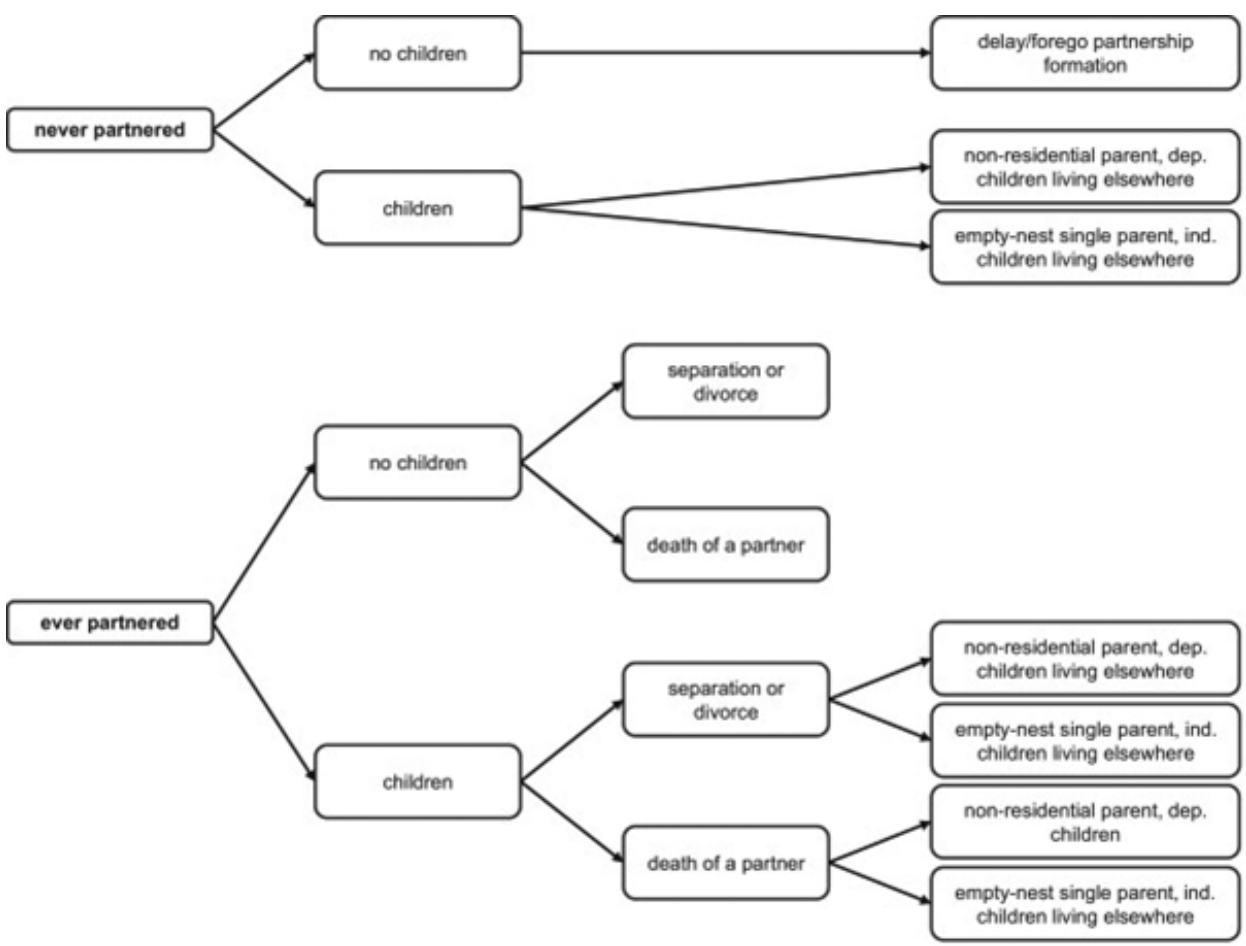

Figure 1. Pathways into living alone

Sources: Demey et al., 2013: 164.

\section{Living apart together, LAT}

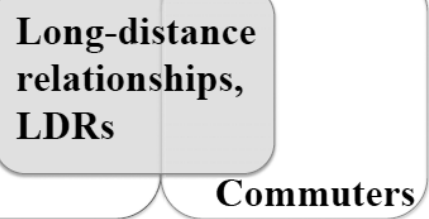

Figure 2. Main terms used to describe non-residential relationships and their relationship to one another as seen by the autor/as discussed in the literature

Sources: Jurkane-Hobein, 2015.

Figure 1 reflects the relationship of concepts and indicates that Long-distance relationships include some characteristics of the other two: for example, couples in such relationships can be married or not, their main distinguishing feature is the 
distance between partners. Moreover, these definitions do not regulate in any way whether partners live alone or have cohabitants, live with their parents, and so on.

Moving away from relationships at a distance towards the processes of individualization, we are faced with the increasingly popular phenomenon of "sologamy". The term itself is used mainly in journalism and is rarely found in scientific discourse, but it is a rather ambiguous phenomenon: marriage to oneself. The phenomenon is prevalent mainly among women and is justified as the institutionalization of self-love. It is worth noting that marrying oneself does not exclude the existence of other relationships (Cabalza, 2018).

Closely related to the concept of solitary living is the concept of "syngilism", it was introduced by the American researcher B. DePaulo. She defines it as stereotyping, stigmatization, and discrimination against people who are not married. In his works, the author defends the idea that the inequality of single people in relation to family people is unfairly hushed up (Gross, 2020).

Based on what was considered above, we can move on to the definition of the concept of "solo-living", but first we will schematically consider how it fits into the general system of concepts:

Table 1. "Solo-living" in the general system of concepts

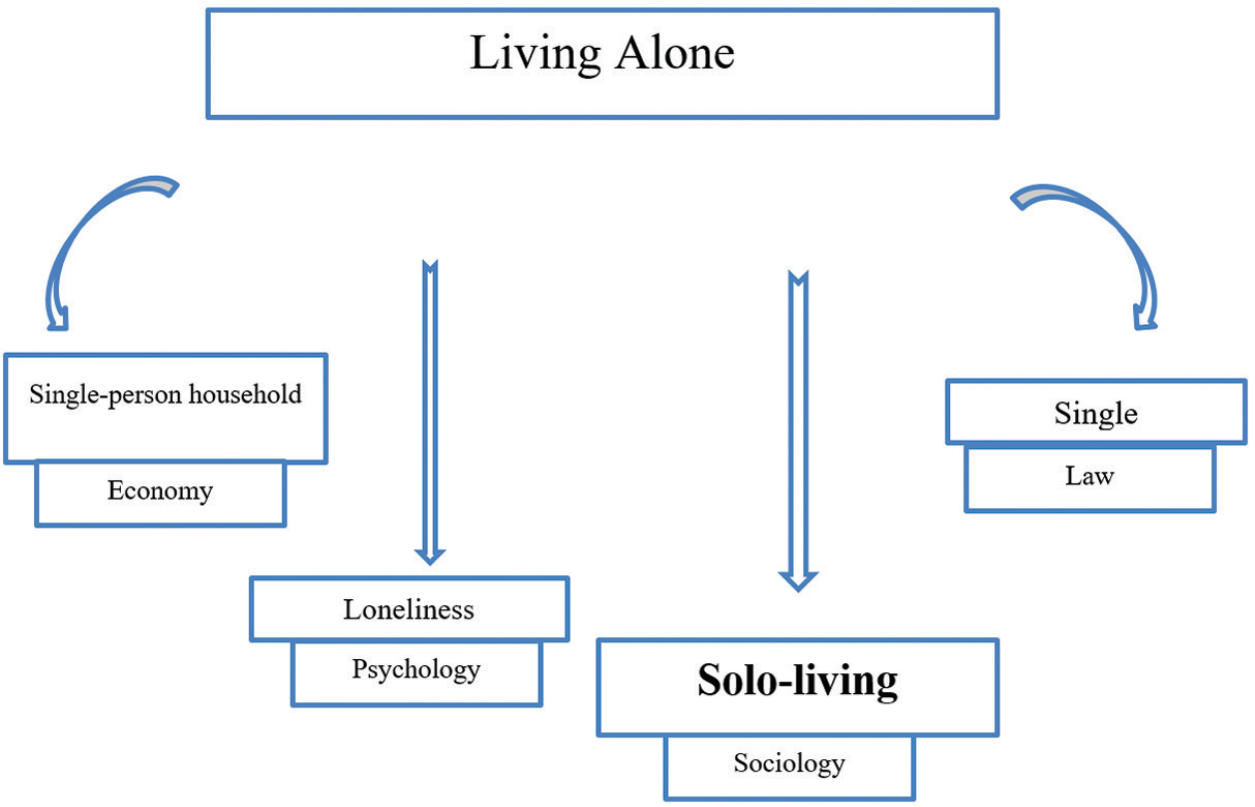

Sources: own elaboration.

The basis of the presented basic concepts, which are most often used interchangeably and synonymously, is solitary living. However, the difference between the presented four concepts lies in the fields of application and field of 
study. So, single households are used in economics, statistics, and demography, formally fixing their number. "Loneliness" is used in psychology to refer to the inner sense of self and the strength of emotional connections. "Single" - reflects the official marital status in official documents, and is used in jurisprudence. "Solo-living" is used in the social sciences to describe individuals who deliberately chose living alone and their practices. At the same time, "solo-living" includes the concept of a single household and the "single" status (the problem is that the relationship between "single" and relations at a distance remains unconsidered - an individual in a relationship at a distance is formally still considered "single", but in fact is not). However, "solo-living" does not include the "lonely" category.

Considering "solo-living" in relation to the other concepts, we can distinguish three main fields in which they can be considered and "solo-living" can be defined as a category that cannot be found and explored within different areas, but rather it is at their intersection. So, we distinguish single households, family/intimate relationships, and social ties.

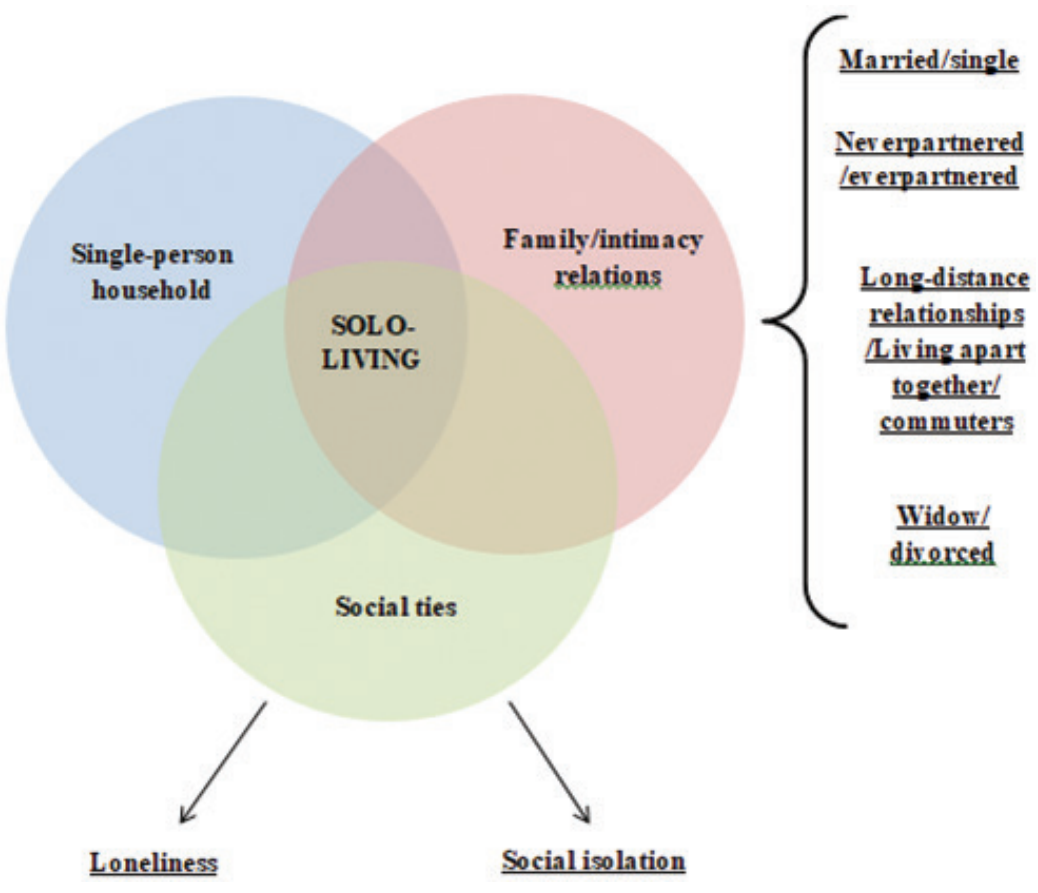

Figure 3. "Solo-living" in relation to related concept Sources: own elaboration.

Thus, we define "solo-living" as a certain lifestyle, which is characterized by a conscious choice of living alone; a lack of an officially fixed marital status "married", a lack of desire to create a family; and economic and social independence. 
From the above, we see that the category "solo-living" is a complex concept that combines elements of concepts from other areas of study, but is not limited to them. If, in economics, the study of single people consists of examining the structure of household income/expenditures, studying consumer behaviour; in psychology, the study of the mental state of individuals and their adaptive abilities; in jurisprudence, in considering the rights and freedoms of individuals living alone; then sociology considers the phenomenon of solitary living, bringing it to the level of social perception/interaction, including the totality of all the above aspects.

Within the framework of this article, we saw that the study of the "sololiving" phenomenon is relevant for many countries and regions, whilst alas not much attention is paid to it, for example, in the countries of Eastern Europe. This observation opens up prospects for further research in this area in the post-Soviet space, and the consideration of "solo-living" as a separate sociological concept makes it possible to study the phenomenon more accurately and in detail. At the same time, one can also highlight the limitations of this study: for example, the topic of the peculiarities of the influence of the cultural context on the choice of the "solo-living" lifestyle and the peculiarities of its manifestation is still not disclosed - this will become a topic for further development.

\section{References}

Abanokova, K. 2015. Izmeneniye struktury domokho zyaystva kak strategiya preodoleniya makroekonomicheskogo shoka. Moskva, https://www.hse.ru/data/2015/06/01/1097846362/ disser_FINAL1.pdf (accessed 20.02.2021).

Baranwal, J., Ram, B. 1985. Societal Development, Familialism and Solo Living: A Cross-National Study. Journal of Comparative Family Studies 16(1), pp. 61-73, https://www.jstor.org/stable/41601530 (accessed 20.02.2021).

Bauman, Z. 2008. Tekuchaia Sovremennost'(Liquid modernity). Moskva: Piter.

Bellani, D., Esping-Andersen, G., Nedoluzhko, L. 2017. Neverpartnered: A multilevelanalysisoflifelongsinglehood. Demographic Research 37, pp. 53-100. DOI: https:// doi.org/10.4054/DemRes.2017.37.4

Berdyaev, N. 1994. I and the world of objects. I am loneliness and society, http://www. vehi.net/berdyaev/mirobj/03.html (accessed 20.02.2021).

Burova, C. 2010. Sotsiologiyabraka i sem 'i: istoriya, teoreticheskiye osnovy, personalii. Belorusskiy gosudarstvennyy universitet. Minsk: Pravo i ekonomika, https://elib.bsu. by/handle/123456789/27676 (accessed 20.02.2021).

Cabalza, Ch. 2018. Goin' Solo: A Study on Singlehood and Viewson 'Sologamy' in the Contemporary Philippine Society. University of the Philippines, Diliman, https:// www.academia.edu/36685047/Goin_Solo_A_Study_on_Singlehood_and_Views_ on_Sologamy_in_the_Contemporary_Philippine_Society (accessed 20.02.2021). 
Chandler, J., Williams, M., Maconachie, M., Collett, T., Dodgeon, B. 2004. Living Alone: Its Place in Household Formationand Change. Sociological Research Online 9(3), pp. 42-54. DOI: https://doi.org/10.5153/sro.971

Demey, D., Berrington, A., Evandrou, M., Falkingham, J., 2013. Path ways into living alone in mid-life: Diversity and policy implications. Advances in Life Course Research 18(3), pp. 161-174. DOI: https://doi.org/10.1016/j.alcr.2013.02.001

Duncan, S., Phillips, M. 2008. Newfamilies? Tradition and changein partnering and relationships. In: A. Park, J. Curtice, K. Thomson, M. Phillips, M.C. Johnson, E. Clery (eds.). British Social Attitudes: the 24th Report. London: SAGE Publications Ltd. DOI: https://doi.org/10.4135/9781849208697.n1

Durkheim, E. 1996. O Razdelenii Obshchestvennogo Truda. Moskva: Kanon.

Ec.europa.eu. 2020a. Household Composition Statistics - Statistics Explained, https:// ec.europa.eu/eurostat/statistics-explained/index.php/Household_composition_statistics (accessed 31.08.2020).

Ec.europa.eu. 2020b. Rising Proportion of Single Person Households in the EU, https://ec.europa. eu/eurostat/web/products-eurostat-news/-/DDN-20180706-1?inheritRedirect=true\#: : text $=$ Your $\% 20$ key $\% 20$ to $\% 20$ European $\% 20$ statistics\&text $=$ The $\% 20$ figures $\% 20$ also \%20show\%20that,in\%202017\%20in\%20the\%20EU (accessed 31.08.2020).

Era.ed.ac.uk. 2005. Solo-living across the adult life course, https://era.ed.ac.uk/bitstream/ handle/1842/2822/rb20.pdf?sequence=1 (accessed 31.08.2020).

Garthwaite, K. 2012. Home Alone? Practitioners' Reflections on the Implications of Young People Living Alone. Youth and Policy 108, pp. 73-87.

Gross, J. 2020. The Price of Being Single. ideas.ted.com. https://ideas.ted.com/the-priceof-being-single (accessed 31.08.2020).

Hall, R., Ogden, P. 2003. The Rise of Living Alone in Inner London: Trends among the Population of Working Age. Environment and Planning A: Economy and Space 35(5), pp. 871-888. DOI: https://doi.org/10.1068/a3549

Härkönen, J., Billingsley, S. Hornung, M. 2020. Divorce Trends in Seven Countries Over the Long Transition from State Socialism: 1981-2004. European Studies of Population, pp. 63-89. DOI: https://doi.org/10.1007/978-3-030-25838-2_4

Jamieson, L., Wasoff, F., Simpson, R. 2009. Solo-Living, Demographic and Family Change: The Need to know more about men. Sociological ResearchOnline 14(2), pp. 20-35. DOI: https://doi.org/10.5153/sro.1888

Jurkane-Hobein, I. 2015. I imagine you here now. Uppsala: Acta Universitatis Uppsalienis.

Khayyek, F. 2000. Individualizm i ekonomicheskiy poryadok (Individualism and economical paradoxes). Tekst. Moskva: Izograf: Nachala-Fond.

Klinenberg, E. 2016. Social Isolation, Loneliness, and Living Alone: Identifying the Risks for Public Health. American Journal of Public Health 106(5), pp. 786-787. DOI: https://doi.org/10.2105/AJPH.2016.303166

Klinenberg, E. 2018. Going solo: The Extraordinary Rise and Surprising Appeal of Living Alone. Moscow: ANF.

Krapf, S. 2017. Movinginor Breaking Up? The Role of Distance in the Development of Romantic Relationships. European Journal of Population 34(3), pp. 313-336. DOI: https://doi.org/10.1007/s10680-017-9428-2 
Lyubimova Ye. 2018. Ponyatiye $i$ analiz issledovaniy zhizni solo. XXI Ural'skiye sotsiologicheskiye chteniya. Sotsial'noye prostranstvo i vremya regiona: problemy ustoychivogo razvitiya: materialy Mezhdunarodnaya nauchno-prakticheskaya konferentsiya (Yekaterinburg, 15-16.03.2018). Yekaterinburg: Gumanitarnyy universitet, pp. 294-297, http://elar.urfu.ru/bitstream/10995/61404/1/978-5-7741-0327-0_068. pdf (accessed 20.02.2021).

Magun, V., Pudnev, M. 2011. Bazovyye tsennosti: skhodstva i razlichiya mezhdu rossiyanami i drugimi yevropeytsami, https://www.hse.ru/data/2010/06/28/1220266818/ Магун, \%20Руднев \%20БАЗОВЫЕ\%20ЦЕННОСТИ\%20СХОДСТВА \% 20 . . ДРУГИМИ\%20ЕВРОПЕЙЦАМИ\%20_симпозиум_.pdf (accessed 20.02.2021).

Mikulioniené, S., Rapoliené, G. 2019. Older people living alone: trends, profiles and challenges of intergenerational integration, https://demotrends.org/2019/11/21/olderpeople-living-alone-trends-profiles-and-challenges-to-intergenerational-integration/ (accessed 20.02.2021).

Mironova, A., Prokof'yeva, L. 2018. Sem'ya i domokhozyaystvo v Rossii: demograficheskiy aspekt. Demograficheskoye obozreniye 5(2), pp. 103-121.

OECD. 2019. Social Policy Division - Directorate of Employment, Labour and Social Affairs. Living arrangements by age groups.

Office for national statistic. 2019. Families and Households in the UK-Office for National Statistics, https://www.ons.gov.uk/peoplepopulationandcommunity/ birthsdeathsandmarriages/families/bulletins/familiesandhouseholds/2019\#thingsyou-need-to-know-about-this-release (accessed 20.02.2021).

Office for national statistic. 2020. Families and Households in the UK-Office for National Statistics, https:/www.ons.gov.uk/peoplepopulationandcommunity/birthsdeathsandma rriages/families/bulletins/familiesandhouseholds/2019\#in-2019-there-were-82million-people-living-alone (accessed 31.08.2020).

Ons.gov.uk. 2020. The Cost of Living Alone - Office for National Statistics, https://www. ons.gov.uk/peoplepopulationandcommunity/birthsdeathsandmarriages/families/ articles/thecostoflivingalone/2019-04-04 (accessed 31.08.2020).

Panina, N. 2008. Izbrannyye trudy po sotsiologii: V trekh tomakh. Teoriya, metody i rezul'taty sotsiologicheskogo issledovaniya obraza zhizni, psikhologicheskogo sostoyaniya $i$ sotsial'nogo samochuvstviya naseleniya. Kiev: FAKT.

Piekut, M. 2020. Living Standardsin One-Person Households of the Elderly Population. Sustainability 12(3), p. 992, https://www.mdpi.com/2071-1050/12/3/992/pdf (accessed 20.02.2021).

Robila, M. 2004. Families in Eastern Europe: Context, Trends and Variation S. Contemporary Perspectives in Family Research pp.1-14. DOI: https://doi.org/10.1016/S15303535(04)05001-0

Simmel, G. 1909. The Problem of Sociology. American Journal of Sociology 15(3), pp. 289-320, http://www.jstor.org/stable/2762513 (accessed 20.02.2021).

Smith, K., Victor, C. 2018. Typologies of loneliness, living alone and social isolation, and their associations with physical and mental health. Ageing and Society 39(8), pp. 1709-1730. DOI: https://doi.org/10.1017/S0144686X18000132 
Statista. 2020a. Norway: Population by Type of Household 2020|Statista, https://www. statista.com/statistics/586942/population-by-type-of-household-in-norway/ (accessed 31.08.2020).

Statista. 2020b. Single-Person Households United States 2019|Statista, https://www.statista.com/ statistics/242022/number-of-single-person-households-in-the-us/ (accessed 31.08.2020).

Unmarried.org. 2020. Living Solo — Unmarried Equality, https://www.unmarried.org/ living-single/ (accessed 31.08.2020).

Vershinina, I. 2012. Sociology of the city by Richard Sennett: Transformation of the Public Sphere. Vestnik Moskovskogo Universiteta. Sotsiologiya i politologiya - Journal of Moscow University. Sociology and Political Science 18(4), pp. 154-161, https://www.socio.msu.ru/vestnik/archive/text/2012/4/10.pdf [in Russian] (accessed 20.02.2021).

Victor, C., Scambler, S., Bond, J., Bowling, A. 2000. Being alone in later life: loneliness, social isolation and living alone. Reviews in Clinical Gerontology 10(4), pp. 407-417.

Wilkinson, K., Tomlinson, J., Gardiner, J. 2018. The perceived fairness of work-life balance policies: A UK case study of solo-living managers and professionals without children. Human Resource Management Journal 28(2), pp. 325-339.

Yashkina, D. 2020. Heuristic potential of emotional labor concepts, trust and public space in the study of solo-living. Ukrainian Society 1, pp. 41-51.

Yeung, W. 2020. Who Will Live Alone in China? One-Person Households in China, 2010 to 2050, http://www.asianmc.org/wp-content/uploads/2019/10/Yeung-Wei-Jun-Jeancompressed.pdf (accessed 20.02.2021). 